to the role of various components of the diet, that is, protein, fat, carbohydrate, various lipotropic substances, vitamins and electrolytes, in altering water absorption. The implication, of course, is that the products of gastro-intestinal absorption may be altered in such a way as to present an abnormal circulating medium to the liver cells.

The present experiments provide a rapid method for the production of liver damage which may be of value in the evaluation of the relative significance of various dietary components, lipotropic, carcinogenic, cirrhogenic and hormonal agents, as related to the prevention and treatment of liver injury.

This work was assisted by a grant from the National Institutes of Health, United States Public Health Service.

Acknowledgment is made for the provision of assistance by Prof. C. H. Li and Dr. H. M. Evans. The participation in phases of this work of J. Schooley and $\mathrm{R}$. Kenigsberg is greatly appreciated.

Department of Anatomy, WM. O. REINHARDT

School of Medicine,

University of California,

Berkeley.

July 20.

1 Himsworth, H. P., "The Liver and its Diseases" (Oxford, 1947). ${ }^{2}$ Gillman, J., and Gillman, T., "Perspectives in Human Malnutrition" (Grune and Stratton, New York, 1951).

${ }^{3}$ Hanzon, V., Acta Physiol. Scand., 28, supp. 101 (1952).

4 Selye, H., Collip, J. B., and Thomson, D. L., Lancet, ii, 297 (1935).

${ }^{5}$ Møller-Christensen, E., Acta Endocrin., 12, 303 (1953).

\section{Reducing Substances in Zostera}

DURING a study of the reduction of sulphates in Zostera mud flats, it was found that when autoclaved Zostera was added to autoclaved sand and sea water, ferrous sulphide was rapidly produced. At first it was thought that this reduction was microbiological, but later it was found that living Zostera could bring about the reduction. A study of Zostera showed that a lead mirror could be produced from lead acetate by heating this substance with Zostera leaves and that this mirror was intracellular in the leaf parenchyma. When washed Zostera leaves are heated with distilled water, cadmium acetate papers show yellow cadmium sulphide, and, at times, metallic cadmium. If the distillation is carried out under nitrogen, the steam distillate condensed into $100 \mathrm{ml}$. of $N / 1,000$ hydrochloric acid at $p H \quad 3 \cdot 35$ yields a nitrogenous solution containing up to $6 \cdot 75 \mathrm{mgm}$. nitrogen per litre, and the $p H$ rises to 7.0 with a volume increase to $450 \mathrm{ml}$. In addition, there is a volatile sulphur-containing substance which is soluble in alcohol and produces lead sulphide from lead acetate. This sulphur compound gives no precipitate with mercuric chloride and a white precipitate with alcoholic lead acetate, suggesting a thioether. It has an unpleasant odour. The production of lead sulphide from lead acetate seems to depend on a partial volatilization of the nitrogenous base. Posidonia appears to contain a different sulphur derivative with a more pungent odour.

Both these substances are present in small amounts and their relative proportions in the plant seem to vary considerably. During October-November, little of the sulphur compound was present in Zostera; but after flowering in January, the sulphur compound increased while the nitrogenous base disappeared. The latter was still present, however, in
Zostera from a bed that was not flowering. These substances are possibly united in the plant with a redox pigment, probably of a dapside glucoside nature.

The existence of these two substances may be of great importance in Zostera muds in two ways : they may produce ferrous sulphide directly, and may also bring about reducing conditions that greatly accelerate sulphate reduction by Microspira.

\section{E. J. Ferguson Wood}

Fisheries Division,

Commonwealth Scientific and

Industrial Research Organization,

Cronulla, N.S.W., Australia.

\section{Action of Insecticides on a Stem Borer of Oats : the Frit Fly}

IN an attempt to assess the possibility of controlling gramineaceous stem borers by systemic and seed. dressing insecticides, the following results were obtained in laboratory and field experiments with larva of flies of the 'frit' complex, Oscinella frit.

Initial tests of the toxicity of 'Pestox 14' or bis dimethylamino-fluorophosphine oxide (Pest Control, Ltd.) to larvæ immersed in aqueous solutions of different strengths showed 71 per cent mortality with 0.0005 per cent and 100 per cent with 0.005 per cent after three days. There was apparently no difference in toxicity to different instars.

Percentage Mortalisy to Mixed Instar Larve of Solutions OF 'PESTOX 14 '

\begin{tabular}{|c|c|c|c|}
\hline $\begin{array}{c}\text { Strength of } \\
\text { solution } \\
\text { (per cent) }\end{array}$ & $\begin{array}{c}\mid 3 \\
\text { (per cent) }\end{array}$ & $\begin{array}{c}\text { Time of immersion } \\
\text { (per cent) }\end{array}$ & $\begin{array}{c}\text { 3 days } \\
\text { (per cent) }\end{array}$ \\
\hline 0.0005 & 0 & 14 & 71 \\
0.005 & 0 & 100 & 100 \\
0.05 & 59 & 100 & 100 \\
0.5 & 100 & 100 & 100 \\
Water & 0 & 0 & 0 \\
\hline
\end{tabular}

'Pestox 14' caused shrivelling of the larva proportional to the concentration and probably due to osmotic dehydration. This effect differs from the turgidity observed in death from parathion.

That translocation of systemic insecticides can occur in members of the Gramineæ is supported by work on the wheat bulb fly (Hylemyia coarctata) by Pest Control, Ltd., by the Overseas Food Corporation on sorghum central shoot borer (Atherigona indica fuscata), by Questell and Conin ${ }^{1}$ on the toxicity of maize tissue to European corn borer (Pyrausta nubilalis), and by death of aphids on young oats grown in pots and watered with 0.05 per cent 'Pestox 3' (octamethylpyrophosphoramide or 'Schradan') after twenty-four hours during the present experiments.

Individual oat seedlings grown in Pfeffer's solution and infected with larvæ in the laboratory were used to demonstrate that 0.1 per cent 'Pestox 3 ' and 0.1 per cent 'Pestox 14' killed all larval stages in the stems in two to three days after the insecticides. were introduced into the culture solutions. With potted seedlings grown in soil, however, watered with 'Pestox 3' at rates to give 50, 180 and 300 parts per million of soil, no dead larva could be found and progressively fewer live larvæ remained in the plants down to none at the 180 p.p.m. level, suggesting a specific repellant action on the larvæ. 